Research article

Open Access

\title{
Tumor necrosis factor alpha and adalimumab differentially regulate CD36 expression in human monocytes
}

\author{
Jean Frédéric Boyer ${ }^{1,2,3}$, Patricia Balard ${ }^{1}$, Hélène Authier ${ }^{1}$, Bruno Faucon ${ }^{2}$, José Bernad ${ }^{1}$, \\ Bernard Mazières ${ }^{3}$, Jean-Luc Davignon ${ }^{3,4}$, Alain Cantagrel2,3, Bernard Pipy ${ }^{1}$ and \\ Arnaud Constantin 2,3,5
}

\author{
1EA2405, Université Paul Sabatier, IFR31, BP84225, 31432 Toulouse CEDEX 4, France \\ 2GRCB40, Université Paul Sabatier, IFR31, BP84225, 31432 Toulouse CEDEX 4, France \\ ${ }^{3}$ Service de Rhumatologie, Centre Hospitalier Universitaire Rangueil, 1 avenue Jean Poulhès, 31059, Toulouse CEDEX 9, France \\ ${ }^{4}$ INSERM, U563, IFR30, BP 3028, 31024 Toulouse CEDEX, France \\ 5INSERM, U558, Faculté de Médecine, 37 allées Jules Guesde, 31073, Toulouse CEDEX 7, France
}

Corresponding author: Arnaud Constantin, constant@cict.fr

Received: 20 Nov 2006 Revisions requested: 11 Jan 2007 Revisions received: 12 Feb 2007 Accepted: 2 Mar 2007 Published: 2 Mar 2007

Arthritis Research \& Therapy 2007, 9:R22 (doi:10.1186/ar2133)

This article is online at: http://arthritis-research.com/content/9/2/R22

(c) 2007 Boyer et al.; licensee BioMed Central Ltd.

This is an open access article distributed under the terms of the Creative Commons Attribution License (http://creativecommons.org/licenses/by/2.0), which permits unrestricted use, distribution, and reproduction in any medium, provided the original work is properly cited.

\begin{abstract}
In chronic inflammatory diseases, such as rheumatoid arthritis, inflammation acts as an independent cardiovascular risk factor and the use of anti-inflammatory drugs, such as anti-tumor necrosis factor alpha (anti-TNF $\alpha$ ), may decrease this risk. The phagocytosis of oxidized low density lipoproteins (LDLs) accumulated in the subendothelium by mononuclear cells influences atherosclerosis and depends on CD36 expression. We investigated the role of TNF $\alpha$ and adalimumab, a human anti-TNF $\alpha$ monoclonal antibody widely used in human pathology, in CD36 expression in human monocytes. Human monocytes were prepared by adherence from whole-blood buffy-coat fractions from healthy donors. CD36 expression was assessed by RT-PCR and flow cytometry, with various TNF $\alpha$ or adalimumab concentrations. Implication of peroxisome proliferator-activated receptor (PPAR) $\gamma$ in the regulation of CD36 expression was assessed using specific inhibitor or gel
\end{abstract}

shift assays. The impact of redox signaling was investigated using quantification of reactive oxygen species, antioxidant and a NADPH oxidase inhibitor. The $F\left(a b^{\prime}\right) 2$ fragment of adalimumab was isolated and its effect was analyzed. TNF $\alpha$ inhibits both CD36 membrane expression and mRNA expression. This inhibition involves a reduction in PPAR $\gamma$ activation. In contrast, adalimumab increases both CD36 membrane expression and mRNA expression. This induction is independent of the Fc portion of adalimumab and involves redox signaling via NADPH oxidase activation. CD36 expression on human monocytes is inhibited by TNF $\alpha$ and independently increased by adalimumab. These data highlight that pro-inflammatory cytokines and their specific neutralization influence the expression of cellular receptors implicated in atherosclerosis. Further studies are needed to investigate the clinical implications of these results in accelerated atherosclerosis observed in rheumatoid arthritis.

\section{Introduction}

In chronic inflammatory diseases, such as rheumatoid arthritis (RA), systemic inflammation appears as an independent risk factor, contributing to increased cardiovascular mortality [1]. This high cardiovascular mortality reveals the existence of accelerated atherosclerosis, the pathogenesis of which may be associated with multiple factors, such as dyslipidemia, deterioration of insulin sensitivity, hyperhomocysteinemia and endothelial dysfunction $[2,3]$. Control of systemic inflammation using conventional drugs, such as methotrexate, or biological therapies, such as anti-tumor necrosis factor alpha (antiTNF $\alpha$ ), provides a means of preventing high cardiovascular mortality among RA patients $[4,5]$.

ABCA1 = ATP-binding cassette transporters A1; DPI = diphenylene iodonium chloride; Fc $\gamma \mathrm{R}=$ Fc gamma receptor; HBSS $=$ Hanks balanced salt solution; IL = interleukin; LDLs = low density lipoproteins; M-SFM = macrophage-serum-free medium; Nrf2 = nuclear factor erythroid 2-related factor $2 ; \mathrm{PBMC}=$ peripheral blood mononuclear cell; $\mathrm{PBS}=$ phosphate-buffered saline; $\mathrm{PPAR}=$ peroxisome proliferator-activated receptor; RA = rheumatoid arthritis; $R O S=$ reactive oxygen species; $R T-P C R=$ reverse transcription $P C R ; S D=$ standard deviation; $S R A=$ scavenger receptor class $A$; TNF $=$ tumor necrosis factor. 
Of the various molecular agents of inflammatory response, proinflammatory cytokines, and TNF $\alpha$ in particular, play a major role in the development of atherosclerosis. TNF $\alpha$ promotes the expression of adhesion molecules, such as vascular cell adhesion molecule-1, E-selectin and intercellular adhesion molecule, necessary for the flow of leucocytes into the subendothelial tissue [6]. It also promotes production of other proinflammatory cytokines and chemokines, such as IL1, IL6 and IL8. Along with interferon- $\gamma$, TNF $\alpha$ plays an important role in atheroma plaque rupture by inducing overexpression of matrix metalloproteinases by macrophages, leading to degradation of the collagen matrix vital to plaque stability [7]. In apolipoprotein-E deficient mice, which provide a valid research model for atherosclerosis, inactivation of the gene encoding TNF $\alpha$ significantly reduces the size of atheroma plaques $[8,9]$. Treating these mice with a fusion protein comprising a type I TNF receptor, neutralizing the TNF $\alpha$, also significantly reduces the size of atheroma plaques $[9,10]$. In humans, neutralizing TNF $\alpha$ using an anti-TNF $\alpha$ monoclonal antibody corrects endothelial dysfunction observed in chronic inflammatory diseases, such as RA and systemic vasculitis [11,12]. Furthermore, TNF $\alpha$ neutralization using either a fusion protein comprising a type II TNF $\alpha$ receptor or an anti-TNF $\alpha$ monoclonal antibody is associated with a reduction in the incidence of first cardiovascular events in RA patients [5].

Among the cellular agents of inflammatory response, mononuclear cells play an essential role in the development of atherosclerosis. Local inflammatory reaction within the atheroma plaque follows the phagocytosis by mononuclear cells of oxidized low density lipoproteins (LDLs) accumulated in the subendothelium [7]. This phagocytosis of oxidized LDLs is caused by scavenger receptors, in particular CD36 and scavenger receptor class $A$ (SRA), and results in the formation of foam cells [13-15]. CD36 is strongly expressed by macrophages within the atheroma plaque [16]. The accumulation of oxidized LDLs by macrophages from subjects naturally deficient in CD36 appears clearly reduced [17]. Different cytokines essential for the regulation of inflammatory and immune responses modulate the expression of CD36 by macrophages. IL4 induces the expression of CD36 by activating the regulatory transcription factor peroxisome proliferator-activated receptor (PPAR) $\gamma$ [18], while transforming growth factor beta represses it [19]. Redox signaling also plays a major role in regulating the expression of CD36. Various products derived from lipid peroxidation induce expression of CD36 by activating regulatory transcription factors, such as nuclear factor erythroid 2-related factor 2 (Nrf2), while vitamin $E$ represses it [20-22]. Some therapeutic agents used in human pathology for their anti-inflammatory properties appear to modulate expression of CD36 by monocytes/macrophages and dendritic cells: aspirin induces expression of CD36 by human macrophages while dexamethasone induces expression of CD36 by dendritic cells $[23,24]$.
These data highlight the key roles played by TNF $\alpha$, mononuclear cells and scavenger receptors in the development of accelerated atherosclerosis observed in chronic human inflammatory diseases. New therapeutic agents that specifically neutralize TNF $\alpha$ have proved to be efficacious in the control of systemic inflammation and in reducing the incidence of cardiovascular events in RA patients [5]. These factors have prompted us to test the hypothesis that CD36 expression in human monocytes is regulated by TNF $\alpha$ and by adalimumab, a human anti-TNF $\alpha$ monoclonal antibody widely used in human pathology. Our work shows differential regulation of CD36 expression by TNF $\alpha$ and adalimumab. Characterizing the mechanisms involved in this differential regulation of CD36 expression may have implications for the prevention of high cardiovascular mortality observed in chronic inflammatory diseases.

\section{Materials and methods}

\section{Isolation and culture of human monocytes}

Peripheral blood mononuclear cells (PBMCs) were isolated from the cytapheresis residues obtained from healthy donors by density gradient on Lymphoprep (AbCys, Paris, France) according to the manufacturer's instructions. The monocytes were isolated from the PBMC by adhesion [25]. The PBMCs were cultured in macrophage-serum-free medium (M-SFM; Gibco Invitrogen, Cergy Pontoise, France) supplemented with L-glutamine at a concentration of $10^{7}$ cells $/ \mathrm{ml}$ for 1.5 hours at $37^{\circ} \mathrm{C}$ with $5 \% \mathrm{CO}_{2}$ in a humid atmosphere. The non-adherent cells were eliminated via three PBS (Eurobio, Les Ulis, France) washes. The adherent cells ( $>85 \%$ of monocytes [26]) were then cultivated in M-SFM in 96-well trays (Becton Dickinson, Le Pont-De-Claix, France) with $0.125 \times 10^{6}$ monocytes/0.125 $\mathrm{ml}$ for reactive oxygen species (ROS) assay, in 24-well trays with $0.5 \times 10^{6}$ monocytes $/ 0.5 \mathrm{ml}$ for flow cytometry tests and gel shift assays, and in 12-well trays with $10^{6}$ monocytes $/ \mathrm{ml}$ for reverse transcription (RT)-PCR tests.

\section{Isolation of $F\left(a b^{\prime}\right) 2$, the antigen binding fragment, from adalimumab}

The isolation of the $F\left(a b^{\prime}\right) 2$ fragment from adalimumab (Abbott France, Rungis, France), a human anti-TNF $\alpha$ lgG1 monoclonal antibody, was carried out by pepsin digestion using the ImmunoPure $F(a b ') 2$ Preparation Kit (Pierce by Interchim, Montluçon, France) according to the manufacturer's instructions. The purity of the $F\left(a b^{\prime}\right) 2$ fragment obtained after adalimumab digestion was verified by migration of the final specimen on a $12 \%$ denaturant acrylamide gel, according to the manufacturer's instructions.

\section{Quantification of membrane expression of CD36 using flow cytometry}

In time-course experiments, monocytes were incubated for 6 to 12 and $24 \mathrm{~h}$ with M-SFM alone or with M-SFM containing TNF $\alpha(10 \mathrm{ng} / \mathrm{ml})$ or adalimumab $(1 \mu \mathrm{g} / \mathrm{ml})$. In additional assays, monocytes were incubated for $24 \mathrm{~h}$ with M-SFM alone 
or with M-SFM containing: human recombinant TNF $\alpha$ at increasing concentrations $(0.1,1$ or $10 \mathrm{ng} / \mathrm{ml}$; BD Biosciences Pharmingen, Le Pont-De-Claix, France); or a combination of $\operatorname{TNF} \alpha(10 \mathrm{ng} / \mathrm{ml})$ or adalimumab $(1 \mu \mathrm{g} / \mathrm{ml}$; a biologically relevant concentration used in human therapeutics [27]; Abbott France) with either TNF $\alpha$ (10 ng/ml), GW9662 ( $2 \mu \mathrm{M}$; Cayman Chemicals by Spi-Bio, Montigny le Bretonneux, France), Trolox ${ }^{\circledR}$ (1 $\mu \mathrm{M}$; Sigma-Aldrich, Saint Quentin Fallavier, France), or diphenylene iodonium chloride (DPI; 1 $\mu \mathrm{M}$; Calbiochem by VWR International, Fontenay sous Bois, France). Rituximab, a human anti-CD20 lgG1 monoclonal antibody (Roche, Meylan, France) was used at the same concentration as adalimumab $(1 \mu \mathrm{g} / \mathrm{ml})$ as control antibody. To investigate the relative contributions of Fab and Fc fragments in the induction of CD36 membrane expression by adalimumab, monocytes were incubated for $24 \mathrm{~h}$ with the $\mathrm{F}\left(\mathrm{ab} \mathrm{b}^{\prime}\right) 2$ fragment of adalimumab $(0.8 \mu \mathrm{g} / \mathrm{ml})$. Quantification of membrane expression of CD36 on monocytes was carried out using flow cytometry according to the following protocol: the monocytes were washed once with PBS and then incubated for 15 minutes at $4^{\circ} \mathrm{C}$ in $5 \mathrm{mM}$ PBS EDTA and collected by aspirating and refilling the wells. The monocytes were then incubated with the anti-CD36 monoclonal antibody labeled with phycoerythrin (BD Bioscience Pharmingen), used at a ratio of $10 \mu \mathrm{l}$ per $0.5 \times 10^{6}$ cells. The background staining was evaluated using a control isotype labeled with phycoerythrin (BD Bioscience Pharmingen) (data not shown). The region of interest of the monocyte population, comprising over 3,000 cells, was isolated on morphological criteria of cell size and granularity. The presence of strong CD14 expression, a characteristic of monocytes, was verified within the region of interest (data not shown). The quantification of membrane expression of CD36 was obtained from the geometric mean of the fluorescence measured [23].

\section{Study of PPAR $\gamma$ activation by gel-shift assay}

Monocytes were incubated with M-SFM alone or with M-SFM containing TNF $\alpha(10 \mathrm{ng} / \mathrm{ml})$ for 5,30 or 60 minutes and then stimulated, or not, by a synthetic ligand of PPAR $\gamma$, rosiglitazone $(5 \mu \mathrm{M})$. Nuclear proteins were then isolated according to the following procedure: the monocytes were lysed at $4^{\circ} \mathrm{C}$ in a hypotonic buffer (10 mM Hepes Free Acid ${ }^{\circledR}$ (Sigma-Aldrich), $10 \mathrm{mM} \mathrm{KCl}, 0.5 \mathrm{mM}$ EDTA, 1 mM MgCl $2,0.1$ mM EGTA) supplemented by anti-proteases (Complete ${ }^{\circledR}$, Roche Diagnostics). Igepal ${ }^{\circledR} \quad(10 \%$; Sigma-Aldrich) was added. The cytoplasmic extracts (supernatants) were isolated after centrifugation and the pellet was replaced in a hypertonic buffer, (20 mM Hepes Free Acid ${ }^{\circledR}, 400$ mM NaCl, 0.5 mM EDTA, 1 mM $\mathrm{MgCl}_{2}, 0.1 \mathrm{mM}$ EGTA) supplemented with anti-proteases $\left(\right.$ Complete ${ }^{\circledR}$ ) in order to extract the nuclear proteins. The proteins were dosed according to the Bradford method.

The oligonucleotide (Santa Cruz Biotechnology by Tebu-Bio, Le Perray en Yvelines, France) used for the shift had the following sequence: 5'-CAAAACTAGGTCAAAGGTCA-3', with the underlined sequence corresponding to the PPAR DNA consensus binding sequence. It was labeled with $\left[\gamma^{-32} \mathrm{P}\right]$ ATP at $37^{\circ} \mathrm{C}$ using $\mathrm{T} 4$ polynucleotide kinase (Promega France, Charbonnières-les-Bains, France) and purified on appropriate columns (Quiagen, Courtaboeuf, France). The probe was labeled at 30,000 to $40,000 \mathrm{cpm} / \mu \mathrm{l}$.

For the DNA protein reaction, $3 \mu \mathrm{g}$ of proteins mixed at ambient temperature with the binding buffer $(2 \mathrm{mM}$ Hepes Free Acid $^{\circledR}, 50 \mathrm{mM} \mathrm{NaCl}, 0.5 \mathrm{mM}$ EDTA, $1 \mathrm{mM} \mathrm{MgCl} 2,4 \%$ glycerol, $2 \mu \mathrm{g} / \mathrm{ml}$ bovine serum albumin, $0.5 \mathrm{mM}$ dithiothreitol), $3 \mu \mathrm{l}$ of labeled oligonucleotides and $0.3 \mu \mathrm{g}$ of poly (dl-dC) (SigmaAldrich) were added in a final volume of $25 \mu \mathrm{l}$ and incubated for 20 minutes at room temperature. The specimens were placed on 5\% non-denaturing acrylamide gel and set to migrate for $2.5 \mathrm{~h}$ at $180 \mathrm{~V}$. The gel was dehydrated under vacuum and exposed by autoradiography.

Analysis of CD36 mRNA expression using real time PCR Monocytes were incubated for $4 \mathrm{~h}$ with M-SFM alone or with M-SFM containing either TNF $\alpha(10 \mathrm{ng} / \mathrm{ml})$, adalimumab $(1 \mu \mathrm{g} /$ $\mathrm{ml})$, or rosiglitazone $(5 \mu \mathrm{M})$ with or without pretreatment with TNF $\alpha(10 \mathrm{ng} / \mathrm{ml})$. The monocytes were lysed in TRIzol ${ }^{\circledR}$ Reagent (Invitrogen) and the mRNA was extracted using the chloroform/isopropanol/ethanol standard procedure. To ascertain that RNA preparations were genomic DNA-free, a negative control reaction was systematically included in which the sample was substituted with water.

PCR for CD36 and $\beta$-actin cDNA was performed with the LC FastStart DNA master SYBR Green I (Roche Diagnostics). Amplification and detection were performed in a LightCycler ${ }^{\circledR}$ system (Roche Diagnostics) as follows, according to the manufacturer's instructions. Reaction mixture $(20 \mu \mathrm{l})$ was incubated initially for 8 minutes at $95^{\circ} \mathrm{C}$ to activate the Fast Start Taq DNA; amplifications were performed for 40 cycles (15 s at $95^{\circ} \mathrm{C}$ and $30 \mathrm{~s}$ at $69^{\circ} \mathrm{C}$ ) for CD36 and $\beta$-actin. The primers were designed with the software Primer Express (Applied Biosystems, Foster City, USA). The primers were: 5'-TGT-AACCCA-GGA-CGC-TGA-GG-3' (sense) and 5'-GAA-GGTTCG-AAG-ATG-GCA-CC-3' (antisense) for CD36; 5'-CCTCAC-CCT-GAA-GTA-CCC-CA-3' (sense) and 5'-TGC-CAGATT-TTC-TCC-ATG-TCG-3' (antisense) for $\beta$-actin.

Real-time PCR data are represented as Ct values, where $\mathrm{Ct}$ is defined as the crossing threshold of PCR using Light-Cycler ${ }^{\circledR}$ Data Analysis software. For calculating relative quantification of CD36 mRNA expression, we used the following procedure: $\Delta \mathrm{CtCD} 36=\mathrm{CtSample}-\mathrm{CtControl}$ and $\Delta \mathrm{Ct} \beta$-actin $=\mathrm{CtSam}-$ ple - CtControl; then, $\Delta \Delta \mathrm{Ct}$ represents the difference between $\Delta \mathrm{Ct} \beta$-actin and $\Delta \mathrm{CtCD} 36$ calculated by the formula $\Delta \Delta \mathrm{Ct}=$ $\Delta \mathrm{Ct} \beta$-actin - $\Delta \mathrm{CtCD} 36$; finally, the $\mathrm{N}$-fold differential expression of CD36 mRNA samples compared to the control is expressed as $2^{\Delta \Delta \mathrm{Ct}}$. 


\section{Quantification of reactive oxygen species production}

Monocytes were incubated for $1 \mathrm{~h}$ with Hanks balanced salt solution (HBSS; Eurobio, Les Ulis, France) alone or with HBSS containing adalimumab $(1 \mu \mathrm{g} / \mathrm{ml}), \mathrm{TNF} \alpha(10 \mathrm{ng} / \mathrm{ml})$ or $\mathrm{F}(\mathrm{ab}) 2(0.8 \mathrm{ng} / \mathrm{ml})$. ROS production was quantified by chemiluminescence in the presence of 5-amino-2,3-dihydro-1,4phthalazinedione (66 mM; Luminol ${ }^{\circledR}$, Sigma-Aldrich) using a thermostatically $\left(37^{\circ} \mathrm{C}\right.$ ) controlled luminometer (Wallac 1420 Victor2, Finland) [26]. The generation of chemiluminescence was monitored continuously for $1 \mathrm{~h}$. Results are expressed as total chemiluminescence emission (area under the curve).

\section{Statistical analysis}

All flow cytometry and real time PCR experiments were performed at least three times. The values are expressed as the mean \pm standard deviation (SD). A Wilcoxon test was used to assess the significance of differences between two conditions. All $p$ values are two-sided, and $p$ values less than 0.05 are considered significant.

\section{Results}

\section{Regulation of CD36 membrane expression by TNF $\alpha$ and} adalimumab

To study the effect of TNF $\alpha$ on the regulation of membrane expression of CD36, monocytes were treated with TNF $\alpha$ (10 $\mathrm{ng} / \mathrm{ml}$ ) for increasing periods of time and membrane expression of CD36 was quantified using flow cytometry. Figure 1a shows that TNF $\alpha$ did not influence membrane expression of CD36 after $6 \mathrm{~h}$ of cell culture in comparison to basal conditions (mean $\pm \mathrm{SD}$ : $91.8 \pm 9.2$ versus $94.2 \pm 11.2,-4 \%, p=$ 0.5). After $12 \mathrm{~h}, \mathrm{TNF} \alpha$ decreased membrane expression of CD36 (46.5 \pm 6.9 versus $82.9 \pm 18.5,-44 \%, p=0.04)$. The strongest effect was observed after $24 \mathrm{~h}$ of cell culture, with a $67 \%$ TNF $\alpha$-induced decrease of CD36 membrane expression (35.3 \pm 15.5 versus $106.9 \pm 11.3, p=0.0004)$. Monocytes were then treated with TNF $\alpha$ at increasing concentrations for $24 \mathrm{~h}$. Figure $1 \mathrm{~b}$ shows that TNF $\alpha$ reduced membrane expression of CD36 in a dose-dependent manner: -9\% (91.6 \pm 10.3 versus $100.3 \pm 10.9, p=0.3),-29 \%$ (71.2 \pm 13.1 versus $100.3 \pm 10.9, p=0.002)$ and $-59 \%(41.4 \pm 4.5$ versus 100.3 $\pm 10.9, p=0.003$ ) for $0.1,1$ and $10 \mathrm{ng} / \mathrm{ml} \mathrm{TNF} \alpha$, respectively, in comparison to basal conditions.

Next, we investigated whether the reduction of membrane expression of CD36 induced by TNF $\alpha$ could be inhibited by adalimumab. Figure $1 \mathrm{c}$ shows that adalimumab $(1 \mu \mathrm{g} / \mathrm{ml})$ inhibited the effect of TNF $\alpha(10 \mathrm{ng} / \mathrm{ml})$ on membrane expression of CD36. Furthermore, adalimumab independently increased membrane expression of CD36 by 59\% (194.9 \pm 42.3 versus $122.8 \pm 23.2, p=0.03$ ) in the presence of TNF $\alpha$ and by $90 \%$ ( $233.7 \pm 49.7$ versus $122.8 \pm 23.2, p=0.04)$ in the absence of TNF $\alpha$, in comparison to basal conditions.

To assess the specificity of adalimumab's effect on membrane expression of CD36, we used rituximab, a human anti-CD20
IgG1 monoclonal antibody, as a control antibody. Figure 1d shows that adalimumab increased CD36 membrane expression $\left(155.3 \pm 24.1\right.$ versus $\left.97.3 \pm 11.7,+60 \%, p=7 \times 10^{-5}\right)$ while rituximab did not influence it $(101.3 \pm 18.5$ versus 97.3 $\pm 11.7,+4 \%, p=0.48$ ), in comparison to basal conditions. Figure 1e shows that adalimumab did not affect CD36 expression after 6 and $12 \mathrm{~h}$, while it increased CD36 expression by $92 \%$ after $24 \mathrm{~h}$ of cell culture $(161.5 \pm 10$ versus $84 \pm 12.4$, $p=0.0003)$ in comparison to basal conditions.

\section{Regulation of CD36 mRNA expression by TNF $\alpha$ and adalimumab}

To study the effect of TNF $\alpha$ and adalimumab on CD36 mRNA expression, the monocytes were treated with TNF $\alpha$ or adalimumab and the relative quantification of CD36 mRNA was carried out by RT-PCR. Figure 2 shows that TNF $\alpha(10 \mathrm{ng} / \mathrm{ml})$ reduced CD36 mRNA expression by $72 \%$ (mRNA relative level \pm SD: $0.28 \pm 0.05, p=0.002)$, while adalimumab $(1 \mu \mathrm{g} /$ $\mathrm{ml}$ ) increased CD36 mRNA expression by $96 \%$ (1.96 $\pm 0.2, p$ $=0.02$ ) in comparison to basal conditions.

\section{Mechanisms involved in the regulation of CD36 expression by TNF $\alpha$}

Since PPAR $\gamma$ is a transcription factor that plays a key role in inducing membrane expression of CD36 on human monocytes [19], we investigated its implication in the regulation of CD36 expression by TNF $\alpha$. We tested the hypothesis that PPAR $\gamma$ activation is inhibited by TNF $\alpha$ using gel-shift assays. The monocytes were incubated with M-SFM alone or with $\mathrm{M}$ SFM containing TNF $\alpha(10 \mathrm{ng} / \mathrm{ml})$ and stimulated, or not, with a synthetic ligand of PPAR $\gamma$, rosiglitazone (5 $\mu \mathrm{M})$, and PPAR $\gamma$ activation was analyzed by gel-shift assay. Figure $3 a$ shows a basal activation of PPAR $\gamma$ that was inhibited by TNF $\alpha$. Rosiglitazone increased the activation of PPAR $\gamma$ and this effect of rosiglitazone was inhibited by TNF $\alpha$.

To evaluate the consequences of the inhibition of PPAR $\gamma$ activation by TNF $\alpha$, we assessed the effect of TNF $\alpha$ on the induction of CD36 mRNA by rosiglitazone. Monocytes were incubated with M-SFM alone or with M-SFM containing TNF $\alpha$ $(10 \mathrm{ng} / \mathrm{ml})$ and stimulated, or not, with rosiglitazone $(5 \mu \mathrm{M})$, and the relative quantification of CD36 mRNA expression was carried out by RT-PCR. Figure $3 b$ shows that TNF $\alpha$ reduced CD36 mRNA expression $(-72 \%, 0.28 \pm 0.05, p=0.002)$, while rosiglitazone increased CD36 mRNA expression $(+46 \%, 1.46 \pm 0.2, p=0.02)$. The combination of TNF $\alpha$ and rosiglitazone inhibited the effect of the rosiglitazone by reducing CD36 mRNA expression $(-59 \%, 0.41 \pm 0.2, p=0.002)$ in comparison to basal conditions.

Since redox signaling is involved in the regulation of CD36 expression in human monocytes $[21,22]$, we analyzed its role in the repression of CD36 membrane expression induced by TNF $\alpha$ (Figure $3 c, d$ ). Monocytes were incubated with TNF $\alpha$ (10 $\mathrm{ng} / \mathrm{ml}$ ) and ROS production was quantified by 
(a)

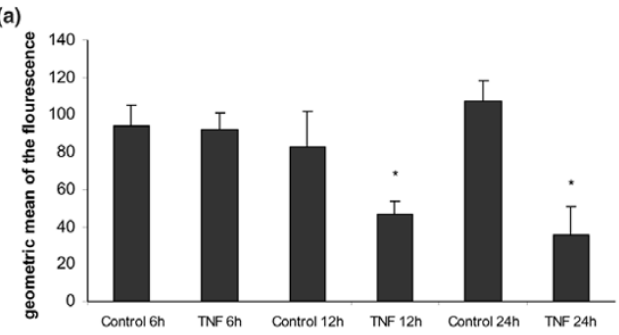

(b)

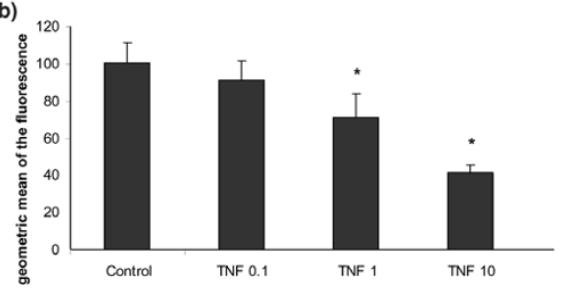

(c)

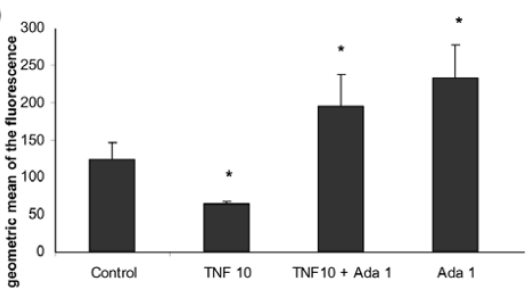

(d)

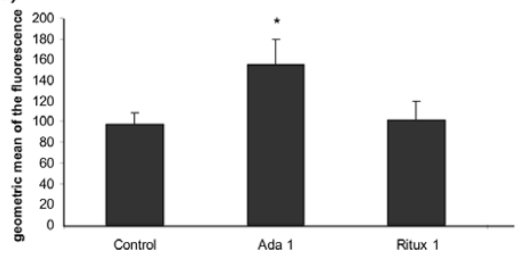

(e)

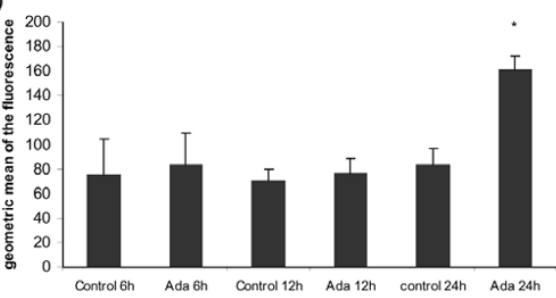

Regulation of CD36 membrane expression by tumor necrosis factor (TNF) $\alpha$ and adalimumab (Ada). (a) TNF $\alpha$ reduces the membrane expression of CD36: time course. Human monocytes were incubated with macrophage-serum-free medium (M-SFM) alone (control), or with M-SFM containing TNF $\alpha(10 \mathrm{ng} / \mathrm{ml})$ for 6 to 12 and $24 \mathrm{~h}$. Membrane expression of CD36 was quantified using flow cytometry. Data represent the geometric mean \pm standard error (SE) of the fluorescence measured in three experiments in duplicate. *Significantly different from control $(p<0.05)$. (b) TNF $\alpha$ reduces membrane expression of CD36: dose effect. Human monocytes were incubated for $24 \mathrm{~h}$ with M-SFM alone (control), or with M-SFM containing TNF $\alpha$ at increasing concentrations $(0.1,1$, or $10 \mathrm{ng} / \mathrm{ml})$ for $24 \mathrm{~h}$. Membrane expression of CD36 was quantified using flow cytometry. Data represent the geometric mean \pm SE of the fluorescence measured in four experiments. * ${ }^{2}$ ignificantly different from control $(p<0.05)$. (c) The reduction of membrane expression of CD36 induced by TNF $\alpha$ is inhibited by adalimumab independently of TNF $\alpha$. Human monocytes were incubated with M-SFM alone (control), or with M-SFM containing either TNF $\alpha$ alone $(10 \mathrm{ng} / \mathrm{ml})$, TNF $\alpha$ combined with adalimumab (Ada; $1 \mu \mathrm{g} / \mathrm{ml})$ or adalimumab alone for $24 \mathrm{~h}$. Membrane expression of CD36 was quantified using flow cytometry. Data represent the geometric mean \pm SE of the fluorescence measured in four experiments. *Significantly different from control $(p<0.05)$. (d) The increase in CD36 membrane expression induced by adalimu$\mathrm{mab}$ is antibody-specific. Human monocytes were incubated with M-SFM alone (control), or with M-SFM containing either adalimumab (Ada; $1 \mu \mathrm{g} /$ $\mathrm{ml}$ ), or rituximab (Ritux; $1 \mu \mathrm{g} / \mathrm{ml}$ ), a human anti-CD20 lgG1 monoclonal antibody, as a control antibody for $24 \mathrm{~h}$. Membrane expression of CD36 was quantified using flow cytometry. Data represent the geometric mean $\pm \mathrm{SE}$ of the fluorescence measured in four experiments in duplicate. ${ }^{*}$ Significantly different from control $(p<0.05)$. (e) Adalimumab increases membrane expression of CD36: time course. Human monocytes were incubated with M-SFM alone (control), or with M-SFM containing adalimumab (Ada; $1 \mu \mathrm{g} / \mathrm{ml}$ ) for 6 to 12 and $24 \mathrm{~h}$. Membrane expression of CD36 was quantified using flow cytometry. Data represent the geometric mean $\pm \mathrm{SE}$ of the fluorescence measured in three experiments in duplicate. ${ }^{*}$ Significantly different from control $(p<0.05)$. 
Figure 2

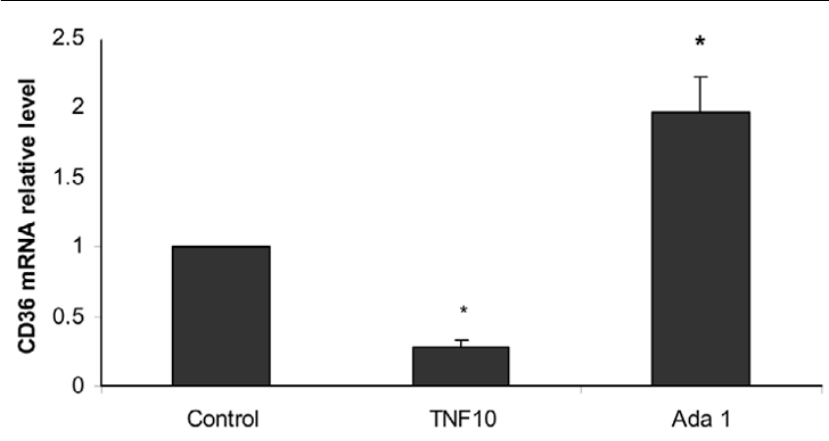

Regulation of CD36 mRNA expression by tumor necrosis factor (TNF) $\alpha$ and adalimumab. TNF $\alpha$ decreases CD36 mRNA expression and adalimumab increases CD36 mRNA expression. Human monocytes were incubated with macrophage-serum-free medium (M-SFM) alone (control), or with M-SFM containing TNF $\alpha(10 \mathrm{ng} / \mathrm{ml})$ or adalimumab (Ada; $1 \mu \mathrm{g} / \mathrm{ml}$ ) for $4 \mathrm{~h}$. CD36 mRNA expression was quantified using RTPCR and normalized to $\beta$-actin. Data represent the mean \pm standard error of the relative quantification of CD36 mRNA expression measured in three experiments. ${ }^{*}$ Significantly different from control $(p<0.05)$.

chemiluminescence for $1 \mathrm{~h}$. Figure 3c shows that TNF $\alpha$ induced a two-fold increase in ROS production in comparison to basal conditions $(45,173 \pm 3,966$ versus $19,207 \pm 4,115$, $p=0.03)$. The role of ROS production in the regulation of CD36 expression induced by TNF $\alpha$ was analyzed using an antioxidant. Monocytes were treated with TNF $\alpha(10 \mathrm{ng} / \mathrm{ml})$, or with an antioxidant derived from vitamin $\mathrm{E}$, Trolox ${ }^{\circledR}(1 \mu \mathrm{M})$, or with a combination of TNF $\alpha$ and Trolox ${ }^{\circledR}$. Membrane expression of CD36 was then quantified using flow cytometry. Figure $3 d$ shows that membrane expression of CD36 was not significantly modified by Trolox ${ }^{\circledR}(76.6 \pm 12$ versus $86.2 \pm 6.8$, $12 \%, p=0.11$ ) in comparison to basal conditions. TNF $\alpha$ decreased CD36 expression (35.9 \pm 7.8 versus $86.2 \pm 6.8$, $\left.52 \%, p=1 \times 10^{-5}\right)$ and this effect was not affected by Trolox ${ }^{\circledR}$ (42. $3 \pm 4$ versus $\left.86.2 \pm 6.8,-60 \%, p=6 \times 10^{-6}\right)$.

\section{Mechanisms involved in the regulation of CD36 expression by adalimumab}

Since PPAR $\gamma$ is a transcription factor that plays a key role in inducing membrane expression of CD36 on human monocytes [19], we investigated its implication in the induction of CD36 membrane expression by adalimumab (Figure 4a). The monocytes were treated with adalimumab $(1 \mu \mathrm{g} / \mathrm{ml})$ or with a PPAR $\gamma$ antagonist, GW9662 (2 $\mu \mathrm{M})$, or with a combination of adalimumab and GW9662, and CD36 expression was quantified using flow cytometry. Figure $4 \mathrm{a}$ shows that adalimumab increased CD36 membrane expression (233.7 \pm 43.7 versus $122.8 \pm 23.2,+70 \%, p=0.02$ ), while GW9662 did not significantly decrease CD36 membrane expression (93.8 \pm 31.8 versus $122.8 \pm 23.2,-24 \%, p=0.2$ ), in comparison to basal conditions. The combination of adalimumab and GW9662 did not inhibit the effect of adalimumab on CD36 membrane expression, which remained increased $(205.5 \pm 24.3$ versus $122.8 \pm 23.2,+67 \%, p=0.003)$. We assessed the effect of
Figure 3
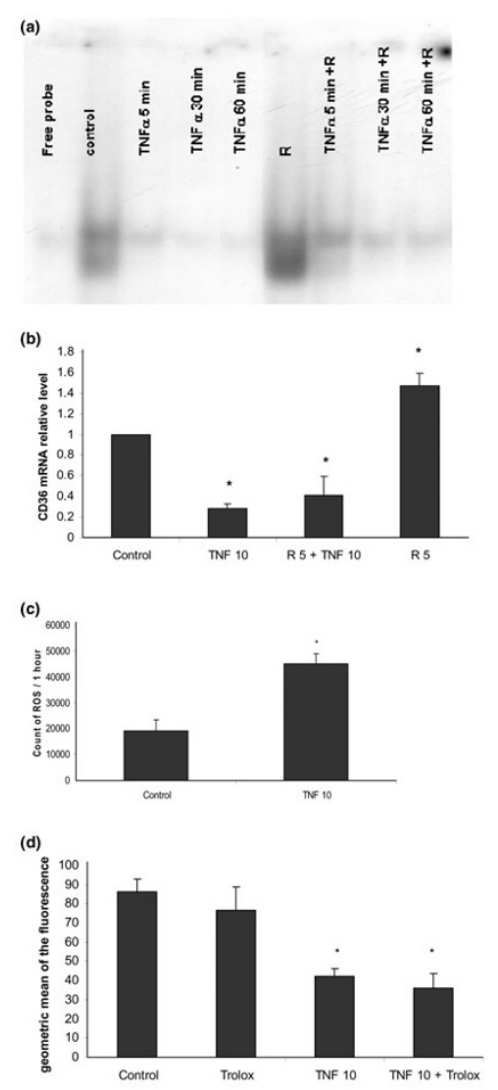

Mechanisms involved in the regulation of CD36 expression by tumor necrosis factor (TNF) $\alpha$. (a) TNF $\alpha$ inhibits both basal and rosiglitazoneinduced peroxisome proliferator-activated receptor (PPAR) $\gamma$ activation. Human monocytes were incubated with macrophage-serum-free medium (M-SFM) alone (control), or with M-SFM containing TNF $\alpha$ (10 $\mathrm{ng} / \mathrm{ml})$ for 5,30 or 60 minutes, and then stimulated, or not, with a synthetic ligand of PPAR $\gamma$, rosiglitazone (R; $5 \mu \mathrm{mol} / \mathrm{l})$ for 45 minutes. Nuclear proteins were isolated and a $\left[\gamma^{-32}\right.$ P]ATP labeled oligonucleotide expressing the PPAR DNA consensus binding sequence was added. PPAR $\gamma$ activation was analyzed by gel-shift assay. (b) TNF $\alpha$ inhibits both basal and rosiglitazone-induced CD36 mRNA expression. Human monocytes were incubated with M-SFM alone (control), or with M-SFM containing TNF $\alpha(10 \mathrm{ng} / \mathrm{ml})$ for $1 \mathrm{~h}$ and then stimulated or not with rosiglitazone (R; $5 \mu \mathrm{mol} / \mathrm{l})$ for $4 \mathrm{~h}$. CD36 mRNA expression was quantified using RT-PCR and normalized to $\beta$-actin. Data represent the mean \pm standard error (SE) of the relative quantification of CD36 mRNA expression measured in three experiments. *Significantly different from control $(p<0.05)$. (c) TNF $\alpha$ induces reactive oxygen species production. Monocytes were incubated with Hanks balanced salt solution (HBSS) alone (control), or with HBSS containing TNF $(10 \mathrm{ng} / \mathrm{ml})$ for $1 \mathrm{~h}$. Reactive oxygen species production was measured by chemiluminescence in the presence of 5-amino-2,3-dihydro-1,4-phthalazinedione in a thermostatically controlled luminometer. Data represent total chemiluminescence emission (area under the curve) for $1 \mathrm{~h}$, measured in three experiments. ${ }^{\star}$ Significantly different from the control $(p<0.05)$. (d) The decrease in CD36 membrane expression induced by TNF $\alpha$ is not inhibited by an anti-oxidant (Trolox). Monocytes were incubated with M-SFM alone (control), or with M-SFM containing either TNF $\alpha$ (10 $\mathrm{ng} / \mathrm{ml})$, Trolox ${ }^{\circledR}(1 \mu \mathrm{M})$, or TNF $\alpha$ combined with Trolox ${ }^{\circledR}$ for $24 \mathrm{~h}$ and the membrane expression of CD36 expression was quantified using flow cytometry. Data represent the geometric mean \pm SE of the fluorescence measured in three experiments in duplicate. *Significantly different from the control $(p<0.05)$ 
adalimumab on PPAR $\gamma$ activation and did not observe any effect in gel shift experiments (data not shown).

To evaluate the role of redox signaling in the induction of CD36 expression observed with anti-TNF $\alpha$, monocytes were incubated with adalimumab $(1 \mu \mathrm{g} / \mathrm{ml})$ and ROS production was quantified by chemiluminescence for $1 \mathrm{~h}$. Figure $4 \mathrm{~b}$ shows that adalimumab induced a two-fold increase in ROS production in comparison to basal conditions (37,095 \pm $1,693$ versus $19,207 \pm 4,115 p=0.008)$. The role of redox signaling in CD36 expression was investigated by using an antioxidant. The monocytes were treated with adalimumab (1 $\mu \mathrm{g} / \mathrm{ml})$ or with an antioxidant derived from vitamin $\mathrm{E}$, Trolox ${ }^{\circledR}(1$ $\mu \mathrm{M})$, or with a combination of adalimumab and Trolox ${ }^{\circledR}$, and membrane expression of CD36 was quantified using flow cytometry. Figure 4c shows that adalimumab increased CD36 membrane expression (168.6 \pm 18.2 versus $86.23 \pm 6.8$, $+96 \%, p=0.001$ ), while Trolox ${ }^{\circledR}$ did not significantly modify it (76.7 \pm 12 versus $86.23 \pm 6.8,-11 \%, p=0.06)$, in comparison to basal conditions. By contrast, the combination of adalimumab and Trolox ${ }^{\circledR}$ inhibited the effect of adalimumab on CD36 membrane expression, which returned to levels observed in basal conditions (81.3 \pm 17 versus $86.23 \pm 6.8$, $-6 \%, p=0.5)$.

Since NADPH oxidase is a key enzyme of oxidative metabolism, inducing production of free radicals in monocytes [28], we investigated its implication in the induction of CD36 membrane expression by adalimumab (Figure 4d). Monocytes were treated with adalimumab $(1 \mu \mathrm{g} / \mathrm{ml})$ or with an NADPH oxidase inhibitor, DPI, or with a combination of adalimumab and DPI, and the membrane expression of CD36 was quantified using flow cytometry. Figure $4 \mathrm{~d}$ shows that adalimumab increased CD36 membrane expression (188.6 \pm 46 versus $88 \pm 10.9$, $+114 \%, p=0.002)$, while DPI decreased it (56.9 \pm 4 versus $88 \pm 10.9,-35 \%, p=0.0003)$, in comparison to basal conditions. In contrast, the combination of adalimumab and DPI inhibited the effect of adalimumab on CD36 membrane expression, which returned to levels observed in basal conditions (108.3 \pm 25.4 versus $88 \pm 10.9,+23 \%, p=0.07)$.

The biological effects of monoclonal antibodies, such as adalimumab, involve both Fab and Fc fragments. The interaction between the $\mathrm{Fc}_{\mathrm{C}}$ fragments of monoclonal antibodies and the $\mathrm{Fc}_{\mathrm{C}}$ gamma receptor $(\mathrm{Fc} \gamma \mathrm{R})$ can activate redox signaling via NADPH oxidase $[29,30]$. To investigate the relative contributions of Fab and Fc fragments in the induction of CD36 membrane expression by adalimumab, we removed the $\mathrm{Fc}$ region from adalimumab through pepsin digestion and isolated the $F(a b ') 2$ region (Figure 5a). The monocytes were treated with the purified $F\left(a b^{\prime}\right) 2$ fragment from adalimumab at an equimolar concentration to that of $1 \mu \mathrm{g} / \mathrm{ml}$ adalimumab $(0.8 \mu \mathrm{g} / \mathrm{ml}$ of $\mathrm{F}\left(\mathrm{ab} \mathrm{b}^{\prime}\right) 2$ fragment being equivalent to $1 \mu \mathrm{g} / \mathrm{ml}$ of adalimumab), and the membrane expression of CD36 was quantified using flow cytometry. Figure $5 b$ shows that the $F\left(a b^{\prime}\right) 2$ fragment of
Figure 4
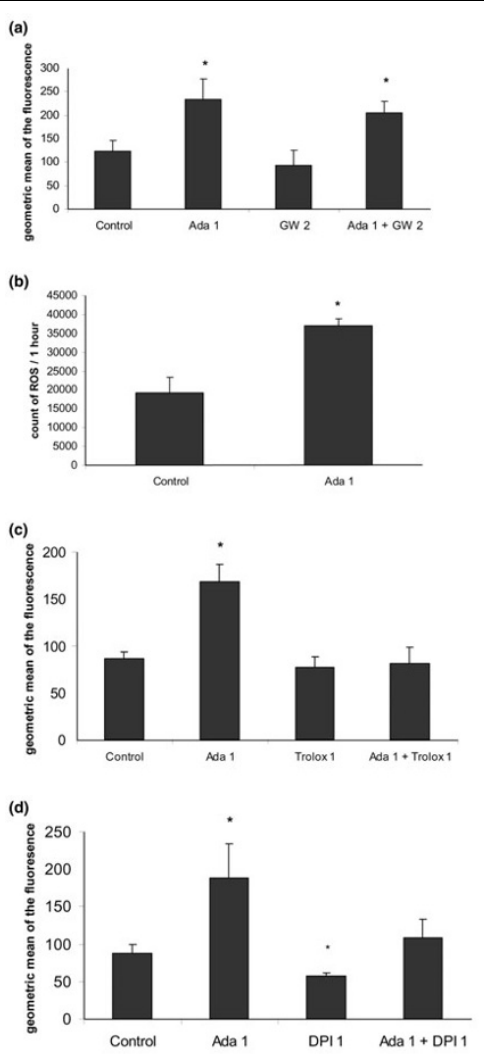

Mechanisms involved in the regulation of CD36 expression by adalimumab. (a) The increase in CD36 membrane expression induced by adalimumab is not inhibited by a peroxisome proliferator-activated receptor (PPAR) $\gamma$ antagonist (GW9662). Monocytes were incubated with macrophage-serum-free medium (M-SFM) alone (control), or with M-SFM containing either adalimumab (Ada; $1 \mu \mathrm{g} / \mathrm{ml})$, GW9662 (GW; $2 \mu \mathrm{M})$, or adalimumab combined with GW9662 for $24 \mathrm{~h}$, and the membrane expression of CD36 was quantified using flow cytometry. Data represent the geometric mean \pm standard error (SE) of the fluorescence measured in three experiments in duplicate. *Significantly different from the control $(p<0.05)$. (b) Adalimumab induces ROS production. Monocytes were incubated with Hanks balanced salt solution (HBSS) alone (control), or with HBSS containing adalimumab (Ada; $1 \mu \mathrm{g} / \mathrm{ml}$ ) for $1 \mathrm{~h}$. Reactive oxygen species production was measured by chemiluminescence in the presence of 5-amino-2,3-dihydro-1,4-phthalazinedione in a thermostatically controlled luminometer. Data represent total chemiluminescence emission (area under the curve) for $1 \mathrm{~h}$, measured in three experiments. ${ }^{*}$ Significantly different from the control $(p<0.05)$. (c) The increase in CD36 membrane expression induced by adalimumab is inhibited by an anti-oxidant (Trolox). Monocytes were incubated with M-SFM alone (control), or with M-SFM containing either adalimu$\mathrm{mab}$ (Ada; $1 \mu \mathrm{g} / \mathrm{ml}$ ), Trolox ${ }^{\circledR}(1 \mu \mathrm{M})$, or adalimumab combined with Trolo $x^{\circledR}$ for $24 \mathrm{~h}$ and the membrane expression of CD36 was quantified using flow cytometry. Data represent the geometric mean \pm SE of the fluorescence measured in three experiments in duplicate. *Significantly different from the control $(p<0.05)$. (d) The increase in CD36 membrane expression induced by adalimumab is inhibited by a NADPH inhibitor (diphenylene iodonium chloride (DPI)). Monocytes were incubated with M-SFM alone (control), or with M-SFM containing either adalimumab (Ada; $1 \mu \mathrm{g} / \mathrm{ml})$, DPI $(1 \mu \mathrm{M})$, or adalimumab combined with $\mathrm{DPI}$ for $24 \mathrm{~h}$ and the membrane expression of CD36 was quantified using flow cytometry. Data represent the geometric mean \pm SE of the fluorescence measured in three experiments in duplicate. *Significantly different from the control $(p<0.05)$ 
adalimumab increased membrane expression of CD36 (140 \pm 20.7 versus $87.5 \pm 7.4,+60 \%, p=0.005$ ) in comparison to basal conditions. Finally, we investigated whether the $F\left(a b^{\prime}\right) 2$ fragment of adalimumab promoted ROS production. Monocytes were incubated with the $F\left(a b^{\prime}\right) 2$ fragment of adalimumab $(0.8 \mu \mathrm{g} / \mathrm{ml})$ and ROS production was quantified by chemiluminescence for $1 \mathrm{~h}$. Figure $5 \mathrm{c}$ shows that the $\mathrm{F}\left(\mathrm{ab} \mathrm{b}^{\prime} 2\right)$ fragment induced a two-fold increase in ROS production in comparison to basal conditions $(39,826 \pm 6,927$ versus $21,873 \pm 3,834$, $p=0.01)$.

\section{Discussion}

Our work demonstrates differential regulation of CD36 expression by TNF $\alpha$ and adalimumab in human monocytes. TNF $\alpha$ inhibits both CD36 membrane expression and mRNA expression. The inhibition of CD36 expression by TNF $\alpha$ involves a reduction in PPAR $\gamma$ activation. Adalimumab independently increases both CD36 membrane expression and mRNA expression. The induction of CD36 expression involves redox signaling via NADPH oxidase activation.

Our study shows that TNF $\alpha$ inhibits both CD36 membrane expression and mRNA expression in human monocytes. Various studies have already shown modulation of CD36 by different cytokines. TNF $\alpha$ and IL1 reduce transcription of fatty acid translocase, homologous to CD36, in hamster adipocytes [31]. IL4 increases CD36 expression in murine macrophages [18] and transforming growth factor beta and IL10 reduce CD36 expression in human macrophages [32,33].

Our study suggests that the inhibition of CD36 expression by TNF $\alpha$ in human monocytes involves a reduction in PPAR $\gamma$ activation. A link between PPAR $\gamma$ and membrane expression of CD36 has already been established in murine macrophages, where deficiency in 12/15 lipoxygenase, an enzyme necessary to generate natural PPAR $\gamma$ ligands, led to a reduction in the expression of CD36 [18]. A reduction in PPAR $\gamma$ activation by TNF $\alpha$ has already been reported in human adipocytes and hepatocytes [34,35], but has not yet been documented in human monocytes. While IL4, a TH2 cytokine, induces CD36 expression via synthesis of natural PPAR $\gamma$ ligands in murine macrophages [18], we suggest that TNF $\alpha$, a TH1 cytokine, inhibits CD36 expression via reduction of PPAR $\gamma$ activation in human monocytes.

Experimental data show that metabolites produced in an oxidative context increase the expression of CD36 in murine macrophages [21]. We demonstrate here that TNF $\alpha$, which induces ROS production, decreases CD36 expression and that this effect is not altered by antioxidant. These results suggest that ROS production is not involved in the repression of CD36 induced by TNF $\alpha$.

Our study shows that adalimumab increases both CD36 membrane expression and mRNA expression in human monocytes.
Figure 5

(a)

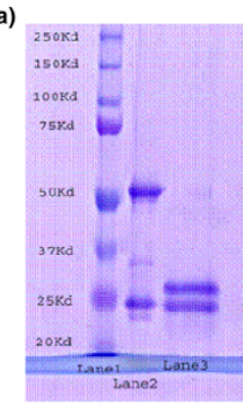

(b)

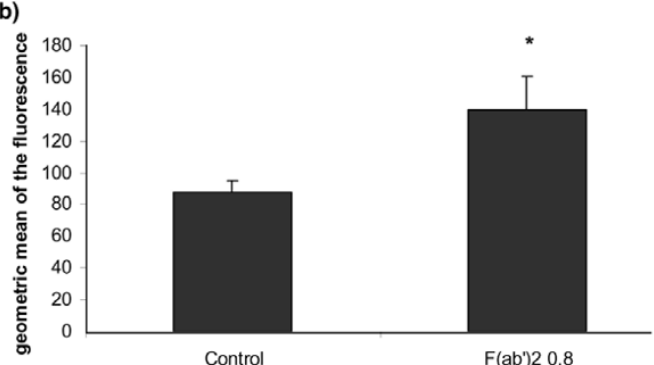

(c)

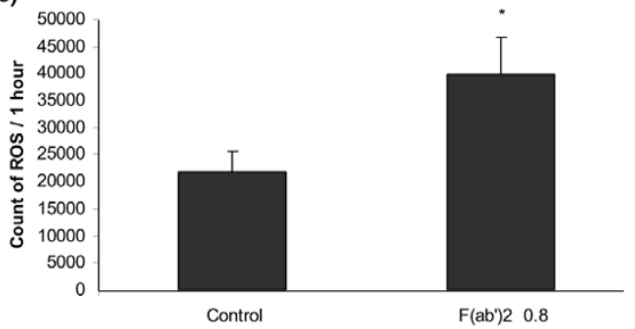

Role of the Fc portion of adalimumab in the regulation of CD36 expression. (a) Isolation of $F\left(a b^{\prime}\right) 2$, the antigen binding fragment, from adalimumab with pepsin digestion. The purity of the $F\left(a b^{\prime}\right) 2$ fragment obtained was verified by migration of the specimens obtained on a $12 \%$ denaturant acrylamide gel according to the manufacturer's instructions. Lane 1 represents the standard molecular weight (20 to $250 \mathrm{kDa})$. Lane 2 represents the light chain $(25 \mathrm{kDa})$ and the heavy chain $(50 \mathrm{kDa})$ of adalimumab. Lane 3 represents the intact light chain $(25 \mathrm{kDa})$ and truncated heavy chain $(30 \mathrm{kDa})$ obtained after pepsin digestion. (b) The $F\left(a^{\prime}\right) 2$ fragment of adalimumab increases membrane expression of CD36. Monocytes were incubated with macrophage-serum-free medium (M-SFM) alone (control), or with M-SFM containing the purified $F\left(a b^{\prime}\right) 2$ fragment from adalimumab at an equimolar concentration to that of $1 \mu \mathrm{g} / \mathrm{ml}$ adalimumab $(0.8 \mu \mathrm{g} / \mathrm{ml}$ of $\mathrm{F}\left(\mathrm{ab} \mathrm{b}^{\prime}\right) 2$ fragment being equivalent to $1 \mu \mathrm{g} / \mathrm{ml}$ of adalimumab) for $24 \mathrm{~h}$ and membrane expression of CD36 in monocytes was quantified using flow cytometry. Data represent the geometric mean \pm standard error of the fluorescence measured in three experiments in duplicate. *Significantly different from the control $(p<0.05)$. (c) The $F(a b ') 2$ fragment of adalimumab induces reactive oxygen species (ROS) production. Monocytes were incubated with Hanks balanced salt solution (HBSS) alone (control), or with HBSS containing $F(a b ') 2(0.8 \mu \mathrm{g} / \mathrm{ml})$ for $1 \mathrm{~h}$. ROS production was measured by chemiluminescence in the presence of 5 amino-2,3-dihydro-1,4-phthalazinedione in a thermostatically controlled luminometer. Data represent total chemiluminescence emission (area under the curve) for $1 \mathrm{~h}$, measured in three experiments. *Significantly different from the control $(p<0.05)$. 
This effect is antibody-specific while rituximab, an IgG1 human antibody directed against CD20, does not influence CD36 membrane expression. The effect of anti-TNF $\alpha$ antibodies on scavenger receptors had not been evaluated before now. Previous work reported that certain pharmacological agents, whose anti-inflammatory properties are used in human therapy, regulate in vitro CD36 expression. Aspirin increases CD36 expression in lines of human THP1 macrophages [23], dexamethasone induces CD36 expression in human dendritic cells from healthy subjects [24] and atorvastatin increases CD36 expression in human monocytes [36,37].

According to the results of our study, the increase in membrane expression of CD36 induced by adalimumab involves a redox signaling pathway via NADPH oxidase activation, but not PPAR $\gamma$. This is in accordance with previous studies showing that products derived from lipid peroxidation induce transcription of CD36 in murine macrophages by activating transcription factors, such as Nrf2 $[21,38]$. On the other hand, the administration of antioxidants, such as vitamin $\mathrm{E}$, leads to a reduction in CD36 expression in murine peritoneal macrophages, and human endothelial cells, and macrophages derived from human monocytes $[20,22,39]$.

Although part of the biological effect of antibodies used in

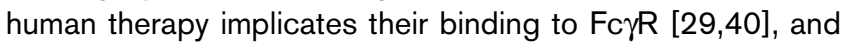
binding of the $F_{c}$ fragment to $F_{C} \gamma R$ activates NADPH oxidase $[30,41]$, the mechanism by which adalimumab increases membrane expression of CD36 appears independent of its Fc fragment. Indeed, the induction of CD36 by adalimumab was specific to the $F\left(a b^{\prime}\right) 2$ portion. The $F\left(a b^{\prime}\right) 2$ fragment increases membrane expression of CD36 and induces ROS production, suggesting that $F\left(a b^{\prime}\right) 2$ and native antibody use the same signaling pathway. The slightly lower induction of CD36 expression observed with the $F\left(a b^{\prime}\right) 2$ fragment in comparison to the native antibody could be explained by a partial alteration of the $F\left(a b^{\prime}\right) 2$ fragments during the pepsin digestion process [42].

We suggest that the $F\left(a b^{\prime}\right) 2$ effect on CD36 expression may partially be the consequence of binding of this fragment of adalimumab to transmembrane TNF $\alpha$. This binding leads to the activation of various intracellular signaling pathways, in particular calcium-dependant pathways, and play a role in the biological activity of anti-TNF $\alpha$ monoclonal antibodies $[43,44]$. Such a reverse signaling phenomenon, resulting from the binding of adalimumab to transmembrane TNF $\alpha$, could account for the differential regulation of CD36 expression by TNF $\alpha$ and adalimumab in human monocytes [45].

Differential regulation of CD36 expression by TNF $\alpha$ and adalimumab in human monocytes may have consequences on the high cardiovascular mortality observed in chronic inflammatory diseases such as RA. In such conditions, anti-TNF $\alpha$ agents appear to reduce the incidence of cardiovascular events [5].
In addition to their anti-inflammatory effect, which seems beneficial in atherosclerosis, anti-TNF $\alpha$ agents could correct endothelial dysfunction and lipid profile abnormalities reported in chronic inflammatory diseases $[11,46]$. The increase in CD36 expression induced by adalimumab reported in our study could contribute to the modulation of cardiovascular risk under anti-TNF $\alpha$ therapies. In murine models of atherosclerosis, ApoE-/- mice, the consequences of inactivating the gene encoding CD36 remain contradictory: a decrease in the formation of atheroma plaques in one case [47], and an increase in the size of atheroma plaques in another [48]. In humans, subjects naturally deficient in CD36 show greater atherosclerosis, which suggests CD36 has an anti-atherogenic role [49]. The increase in CD36 expression induced in vitro by pharmacological agents such as aspirin and atorvastatin, whose antiatherogenic effects are clearly established in human therapy, would suggest that this may be the case $[23,37]$.

\section{Conclusion}

Our work demonstrates differential regulation of CD36 expression by TNF $\alpha$ and adalimumab in human monocytes. While TNF $\alpha$ inhibits both CD36 membrane expression and mRNA expression, an anti-TNF $\alpha$ monoclonal antibody, adalimumab, independently increases both CD36 membrane expression and mRNA expression. Better understanding of the impact of anti-inflammatory therapeutic agents, such as antiTNF $\alpha$, on scavenger receptors, such as CD36 and SRA, and membrane reverse cholesterol transporters, such as ATPbinding cassette transporters A1 (ABCA1), may have implications for the prevention of high cardiovascular mortality observed in chronic inflammatory diseases.

\section{Competing interests}

The authors declare that they have no competing interests.

\section{Authors' contributions}

JFB was involved in the design of the study, performed all the experiments and wrote the manuscript. PB was involved in performing cell cultures, flow cytometry and gel shift assays, and reviewed the article critically. HA was involved in performing RT-PCR. BF was involved in $F\left(a b^{\prime}\right) 2$ isolation. JB isolated PBMCs from healthy donors. BM revised the article critically. JLD was involved in the design of the study and reviewed the article critically. AC was involved in the conception and design of this study, in the interpretation of data and reviewed this article critically. BP and $\mathrm{ArC}$ co-directed the conception and design of this study, participated in the interpretation of data and in the preparation of the manuscript and gave final approval of the manuscript for publication. All authors read and approved the final manuscript.

\section{Acknowledgements}

This work was financed by the EA2405 and the GRCB40 unit and conducted independently of the Abbott Laboratory. 


\section{References}

1. Maradit-Kremers H, Nicola PJ, Crowson CS, Ballman KV, Gabriel SE: Cardiovascular death in rheumatoid arthritis: a populationbased study. Arthritis Rheum 2005, 52:722-732.

2. Gonzalez-Gay MA, Gonzalez-Juanatey C, Martin J: Rheumatoid arthritis: a disease associated with accelerated atherogenesis. Semin Arthritis Rheum 2005, 35:8-17.

3. Snow MH, Mikuls TR: Rheumatoid arthritis and cardiovascular disease: the role of systemic inflammation and evolving strategies of prevention. Curr Opin Rheumatol 2005, 17:234-241.

4. Choi HK, Hernan MA, Seeger JD, Robins JM, Wolfe F: Methotrexate and mortality in patients with rheumatoid arthritis: a prospective study. Lancet 2002, 359:1173-1177.

5. Jacobsson LT, Turesson C, Gulfe A, Kapetanovic MC, Petersson IF, Saxne T, Geborek P: Treatment with tumor necrosis factor blockers is associated with a lower incidence of first cardiovascular events in patients with rheumatoid arthritis. J Rheumatol 2005, 32:1213-1218.

6. Tousoulis D, Davies G, Stefanadis C, Toutouzas P, Ambrose JA: Inflammatory and thrombotic mechanisms in coronary atherosclerosis. Heart 2003, 89:993-997.

7. Lusis AJ: Atherosclerosis. Nature 2000, 407:233-241.

8. Meir KS, Leitersdorf E: Atherosclerosis in the apolipoprotein-Edeficient mouse: a decade of progress. Arterioscler Thromb Vasc Biol 2004, 24:1006-1014.

9. Branen L, Hovgaard L, Nitulescu M, Bengtsson E, Nilsson J, Jovinge $S$ : Inhibition of tumor necrosis factor-alpha reduces atherosclerosis in apolipoprotein E knockout mice. Arterioscler Thromb Vasc Biol 2004, 24:2137-2142.

10. Elhage R, Maret A, Pieraggi MT, Thiers JC, Arnal JF, Bayard F: Differential effects of interleukin-1 receptor antagonist and tumor necrosis factor binding protein on fatty-streak formation in apolipoprotein E-deficient mice. Circulation 1998, 97:242-244.

11. Hurlimann D, Forster A, Noll G, Enseleit F, Chenevard R, Distler O, Bechir M, Spieker LE, Neidhart M, Michel BA, et al.: Anti-tumor necrosis factor-alpha treatment improves endothelial function in patients with rheumatoid arthritis. Circulation 2002, 106:2184-2187.

12. Booth $A D$, Jayne $D R$, Kharbanda RK, McEniery CM, Mackenzie IS, Brown J, Wilkinson IB: Infliximab improves endothelial dysfunction in systemic vasculitis: a model of vascular inflammation. Circulation 2004, 109:1718-1723.

13. Huh HY, Pearce SF, Yesner LM, Schindler JL, Silverstein RL: Regulated expression of CD36 during monocyte-to-macrophage differentiation: potential role of CD36 in foam cell formation. Blood 1996, 87:2020-2028.

14. Lougheed M, Lum CM, Ling W, Suzuki H, Kodama T, Steinbrecher $U$ : High affinity saturable uptake of oxidized low density lipoprotein by macrophages from mice lacking the scavenger receptor class A type I/II. J Biol Chem 1997, 272:12938-12944

15. Kunjathoor VV, Febbraio M, Podrez EA, Moore KJ, Andersson L, Koehn S, Rhee JS, Silverstein R, Hoff HF, Freeman MW: Scavenger receptors class A-I/II and CD36 are the principal receptors responsible for the uptake of modified low density lipoprotein leading to lipid loading in macrophages. J Biol Chem 2002, 277:49982-49988.

16. Nakata A, Nakagawa $Y$, Nishida M, Nozaki S, Miyagawa J, Nakagawa T, Tamura R, Matsumoto K, Kameda-Takemura K, Yamashita $\mathrm{S}$, et al.: CD36, a novel receptor for oxidized low-density lipoproteins, is highly expressed on lipid-laden macrophages in human atherosclerotic aorta. Arterioscler Thromb Vasc Biol 1999, 19:1333-1339.

17. Nozaki S, Kashiwagi $H$, Yamashita $S$, Nakagawa T, Kostner B, Tomiyama $Y$, Nakata A, Ishigami M, Miyagawa J, Kameda-Takemura $\mathrm{K}$, et al.: Reduced uptake of oxidized low density lipoproteins in monocyte-derived macrophages from CD36-deficient subjects. J Clin Invest 1995, 96:1859-1865.

18. Huang JT, Welch JS, Ricote M, Binder CJ, Willson TM, Kelly C, Witztum JL, Funk CD, Conrad D, Glass CK: Interleukin-4dependent production of PPAR-gamma ligands in macrophages by 12/15-lipoxygenase. Nature 1999, 400:378-382.

19. Febbraio M, Hajjar DP, Silverstein RL: CD36: a class B scavenger receptor involved in angiogenesis, atherosclerosis, inflammation, and lipid metabolism. J Clin Invest 2001, 108:785-791.
20. Ricciarelli R, Zingg JM, Azzi A: Vitamin E reduces the uptake of oxidized LDL by inhibiting CD36 scavenger receptor expression in cultured aortic smooth muscle cells. Circulation 2000, 102:82-87.

21. Ishii T, Itoh K, Ruiz E, Leake DS, Unoki H, Yamamoto M, Mann GE: Role of Nrf2 in the regulation of CD36 and stress protein expression in murine macrophages: activation by oxidatively modified LDL and 4-hydroxynonenal. Circ Res 2004, 94:609-616.

22. Devaraj S, Hugou I, Jialal I: Alpha-tocopherol decreases CD36 expression in human monocyte-derived macrophages. J Lipid Res 2001, 42:521-527.

23. Vinals M, Bermudez I, Llaverias G, Alegret $M$, Sanchez RM, Vazquez-Carrera M, Laguna JC: Aspirin increases CD36, SR-BI, and ABCA1 expression in human THP-1 macrophages. Cardiovasc Res 2005, 66:141-149.

24. Matasic R, Dietz AB, Vuk-Pavlovic S: Dexamethasone inhibits dendritic cell maturation by redirecting differentiation of a subset of cells. J Leukoc Biol 1999, 66:909-914.

25. Jiang C, Ting AT, Seed B: PPAR-gamma agonists inhibit production of monocyte inflammatory cytokines. Nature 1998, 391:82-86.

26. Bureau C, Bernad J, Chaouche N, Orfila C, Beraud M, Gonindard C, Alric L, Vinel JP, Pipy B: Nonstructural 3 protein of hepatitis $C$ virus triggers an oxidative burst in human monocytes via activation of NADPH oxidase. J Biol Chem 2001, 276:23077-23083.

27. Nestorov I: Clinical pharmacokinetics of TNF antagonists: how do they differ? Semin Arthritis Rheum 2005, 34(5 Suppl 1): $12-18$

28. Iles $\mathrm{KE}$, Forman $\mathrm{HJ}$ : Macrophage signaling and respiratory burst. Immunol Res 2002, 26:95-105.

29. Clynes RA, Towers TL, Presta LG, Ravetch JV: Inhibitory Fc receptors modulate in vivo cytoxicity against tumor targets. Nat Med 2000, 6:443-446.

30. Melendez AJ, Bruetschy L, Floto RA, Harnett MM, Allen JM: Functional coupling of FcgammaRI to nicotinamide adenine dinucleotide phosphate (reduced form) oxidative burst and immune complex trafficking requires the activation of phospholipase D1. Blood 2001, 98:3421-3428.

31. Memon RA, Feingold KR, Moser AH, Fuller J, Grunfeld C: Regulation of fatty acid transport protein and fatty acid translocase mRNA levels by endotoxin and cytokines. Am J Physiol 1998, 274:E210-217.

32. Draude G, Lorenz RL: TGF-beta1 downregulates CD36 and scavenger receptor $\mathrm{A}$ but upregulates LOX-1 in human macrophages. Am J Physiol Heart Circ Physiol 2000, 278:H1042-1048.

33. Rubic T, Lorenz RL: Downregulated CD36 and oxLDL uptake and stimulated $A B C A 1 / G 1$ and cholesterol efflux as antiatherosclerotic mechanisms of interleukin-10. Cardiovasc Res 2006, 69:527-535.

34. Suzawa M, Takada I, Yanagisawa J, Ohtake F, Ogawa S, Yamauchi T, Kadowaki T, Takeuchi Y, Shibuya H, Gotoh Y, et al:: Cytokines suppress adipogenesis and PPAR-gamma function through the TAK1/TAB1/NIK cascade. Nat Cell Biol 2003, 5:224-230.

35. Sung $\mathrm{CK}$, She H, Xiong S, Tsukamoto $\mathrm{H}$ : Tumor necrosis factoralpha inhibits peroxisome proliferator-activated receptor gamma activity at a posttranslational level in hepatic stellate cells. Am J Physiol Gastrointest Liver Physiol 2004, 286:G722-729.

36. McCarey DW, Mclnnes IB, Madhok R, Hampson R, Scherbakov O Ford I, Capell HA, Sattar N: Trial of Atorvastatin in Rheumatoid Arthritis (TARA): double-blind, randomised placebo-controlled trial. Lancet 2004, 363:2015-2021.

37. Ruiz-Velasco N, Dominguez A, Vega MA: Statins upregulate CD36 expression in human monocytes, an effect strengthened when combined with PPAR-gamma ligands putative contribution of Rho GTPases in statin-induced CD36 expression. Biochem Pharmacol 2004, 67:303-313.

38. Motohashi H, Yamamoto M: Nrf2-Keap1 defines a physiologically important stress response mechanism. Trends Mol Med 2004, 10:549-557.

39. Fuhrman B, Volkova N, Aviram M: Oxidative stress increases the expression of the CD36 scavenger receptor and the cellular uptake of oxidized low-density lipoprotein in macrophages 
from atherosclerotic mice: protective role of antioxidants and of paraoxonase. Atherosclerosis 2002, 161:307-316.

40. Samuelsson A, Towers TL, Ravetch JV: Anti-inflammatory activity of IVIG mediated through the inhibitory Fc receptor. Science 2001, 291:484-486.

41. Pfefferkorn LC, Fanger MW: Cross-linking of the high affinity Fc receptor for human immunoglobulin G1 triggers transient activation of NADPH oxidase activity. Continuous oxidase activation requires continuous de novo receptor cross-linking. J Biol Chem 1989, 264:14112-14120.

42. Morais V, Massaldi $H$ : Effect of pepsin digestion on the antivenom activity of equine immunoglobulins. Toxicon 2005 , 46:876-882.

43. Mitoma H, Horiuchi T, Hatta N, Tsukamoto H, Harashima S, Kikuchi Y, Otsuka J, Okamura S, Fujita S, Harada M: Infliximab induces potent anti-inflammatory responses by outside-to-inside signals through transmembrane TNF-alpha. Gastroenterology 2005, 128:376-392.

44. Watts $A D$, Hunt $\mathrm{NH}$, Wanigasekara $\mathrm{Y}$, Bloomfield G, Wallach D, Roufogalis BD, Chaudhri G: A casein kinase I motif present in the cytoplasmic domain of members of the tumour necrosis factor ligand family is implicated in 'reverse signalling'. EMBO J 1999, 18:2119-2126.

45. Eissner G, Kolch W, Scheurich P: Ligands working as receptors: reverse signaling by members of the TNF superfamily enhance the plasticity of the immune system. Cytokine Growth Factor Rev 2004, 15:353-366.

46. Popa C, Netea MG, Radstake T, Van der Meer JW, Stalenhoef AF, van Riel PL, Barerra P: Influence of anti-tumour necrosis factor therapy on cardiovascular risk factors in patients with active rheumatoid arthritis. Ann Rheum Dis 2005, 64:303-305.

47. Febbraio M, Podrez EA, Smith JD, Hajiar DP, Hazen SL, Hoff HF, Sharma K, Silverstein RL: Targeted disruption of the class B scavenger receptor $\mathrm{CD} 36$ protects against atherosclerotic lesion development in mice. J Clin Invest 2000, 105:1049-1056.

48. Moore KJ, Kunjathoor VV, Koehn SL, Manning JJ, Tseng AA, Silver $\mathrm{JM}$, McKee M, Freeman MW: Loss of receptor-mediated lipid uptake via scavenger receptor A or CD36 pathways does not ameliorate atherosclerosis in hyperlipidemic mice. J Clin Invest 2005, 115:2192-2201.

49. Hirano K, Kuwasako T, Nakagawa-Toyama $Y$, Janabi M, Yamashita S, Matsuzawa Y: Pathophysiology of human genetic CD36 deficiency. Trends Cardiovasc Med 2003, 13:136-141. 